\title{
Killing of Escherichia coli by human polymorphonuclear leucocytes in the presence of Bacteroides fragilis
}

\author{
WAC VEL, F NAMAVAR, AMJJ VERWEIJ-VAN VUGHT, ANB PUBBEN, DM MACLAREN \\ From the Research Group for Commensal Infections, Vrije Universiteit, Departments of Medical and Oral \\ Microbiology, Amsterdam, The Netherlands
}

SUMMARY The inhibitory effect of Bacteroides fragilis on the in vitro killing of Escherichia coli by polymorphonuclear leucocytes was studied with two pairs of $E$ coli and $B$ fragilis isolated from human wound infections. Both $B$ fragilis strains behaved similarly: they inhibited the killing of one $E$ coli strain, while the killing of the other $E$ coli strain was not affected. The different behaviour of the two $E$ coli strains depended on their need for fresh serum in the killing by the polymorphonuclear leucocytes. The inhibitory effect of the $B$ fragilis strains could be completely accounted for by their effect on complement.

The early bacteriologists who had to convince a sceptical world of the role of bacteria in disease laid great emphasis on isolating pure cultures from infected lesions. This need for pure cultures is implicit in the famous postulates of Koch. Although it was soon realised that bacterial species seemed to assist each other in producing infections - for example, Meleney's synergistic gangrene and foot rot in sheep-most attention was paid to identifying pure cultures as causative micro-organisms. Recently, the increasing importance of commensal infections, such as wound infections and infections after gastrointestinal surgery, has stimulated interest in bacteria which seem to play a synergistic role with each other. An understanding of their interplay is important not only for elucidating the paihogenesis of the infection but also for optimal diagnosis and treatment. The well known synergy between members of the genus bacteroides and enterobacteria has been variously explained. One possible explanation is the inhibitory effect that these anaerobic bacteria have on the in vitro phagocytosis of enterobacteria, as described by several authors. ${ }^{-5}$

In 1981 Tofte et al suggested that the inhibitory effect of $B$ fragilis on the killing of $E$ coli by polymorphonuclear leucocytes could be explained by competition for opsonins. ${ }^{6}$ The results of the in vitro experiments mentioned above support this theory. On the other hand, whereas synergy bet-

Accepted for publication 26 September 1984 ween $E$ coli and $B$ fragilis has been shown in animal models, ${ }^{7-9}$ in vivo Reznikov et al ${ }^{10}$ found no inhibition of phagocytosis of aerobes by anaerobes. Thus a direct relation between in vivo observations and in vitro findings is still missing.

While most of the work in animal models has been carried out with $B$ fragilis and $E$ coli, the combination most often encountered in abdominal abscesses, " most in vitro work has adopted rather arbitrary combinations of $B$ fragilis or asaccharolytic bacteroides species and Proteus mirabilis or $E$ coli. The purpose of this study was to investigate the in vitro inhibitory effect of the anaerobes on the killing of the aerobes by polymorphs in two pairs of $E$ coli and $B$ fragilis which had been isolated from wound infections. In a parallel study these pairs were tested for their in vivo synergistic effect. ${ }^{9}$

\section{Material and methods}

BACTERIAL STRAINS

The two pairs of $E$ coli and $B$ fragilis used in this study were collected from infected wounds in patients of the Academic Hospital of the Vrije Universiteit. $E$ coli $\mathrm{EB} 1$ and $B$ fragilis $\mathrm{BE} 1$ were isolated from the same abscess; no other bacterial species was cultured. $E$ coli $\mathrm{EB} 4$ and $B$ fragilis BE4 were found in an abscess of another patient together with three other species: Acidaminococcus fermentans, Eubacterium lentum, and $B$ distasonis. The $E$ coli strains were identified with API 20 E (API sys- 
tem SA, Montalien Vercien, France) and the anaerobic strains with the BBL Minitek numerical identification system (BBL Microbiology systems, Becton and Dickinson, USA).

$E$ coli strains were cultured aerobically in nutrient broth (Lab Lemco, Oxoid, England). $B$ fragilis strains were grown in liquid BM medium ${ }^{12}$ supplemented with haemin $(5 \mu \mathrm{g} / \mathrm{ml}, \mathrm{BDH}$, Poole, England) and menadione $(2 \mu \mathrm{g} / \mathrm{ml}, \mathrm{E}$ Merck $A G$, Darmstadt, West Germany) at $37^{\circ}$ in an anaerobic chamber (Coy's Manufacturing Co, Ann Arbor, Michigan, USA) in an atmosphere of $85 \% \mathrm{~N}_{2}, 10 \%$ $\mathrm{H}_{2}$, and $5 \% \mathrm{CO}_{2}$. Bacteria were maintained as a mixture of $1 \mathrm{ml}$ of pure culture and $1 \mathrm{ml}$ of $60 \%$ glycerol and frozen at $-70^{\circ} \mathrm{C}$.

For each experiment the $E$ coli strains from the frozen stock culture were grown on a nutrient plate, and a single colony was inoculated on to nutrient broth and cultured until in late log phase. Bacteria were washed three times and resuspended in phosphate buffered saline (PBS). Viable counts were performed by plating serial dilutions on nutrient agar plates. The bacterial suspension was kept overnight at $4^{\circ} \mathrm{C}$, and the next day adjusted to $10^{8}$ colony forming units per millilitre.

Anaerobic bacteria from the frozen stock culture were cultured on a BM agar plate supplemented with $5 \%$ sheep blood, haemin, and menadione. A pure culture from a single colony was grown in liquid $\mathrm{BM}$ medium with haemin and menadione at $37^{\circ} \mathrm{C}$ in the anaerobic chamber. After $18 \mathrm{~h}$ the cultures contained $2-5 \times 10^{8}$ colony forming units per millilitre, as determined by viable counts. Unless the whole culture was used, the bacteria were washed once in PBS and resuspended to the original volume.

In some experiments bacteria were killed by incubating them for $1 \mathrm{~h}$ at $70^{\circ} \mathrm{C}$ or by shaking the bacteria for $30 \mathrm{~min}$ with $0.5 \%$ formalin. In both cases the bacteria were washed afterwards and resuspended in PBS to the original volume.

In some experiments Staphylococcus aureus (Oxford strain) NCTC 6571 was used; it was cultured and treated as described for $E$ coli.

\section{POLYMORPHONUCLEAR LEUCOCYTES}

Polymorphs were separated from heparinised blood of healthy donors by dextran sedimentation. They were washed three times with Hank's balanced salt solution (HBSS) (Gibco Laboratory, Grand Island, NY) with $0.1 \%$ gelatin, buffered with bicarbonate at pH 7.3 (gel-HBSS), and suspended to a concentration of $10^{7}$ cells $/ \mathrm{ml}$.

\section{SERUM}

Pooled human serum from healthy human donors was used in all experiments as the source of opsonins. In experiments with preopsonised $E$ coli $10^{8}$ bacteria were incubated with $50 \%$ serum in $1 \mathrm{ml}$ PBS in a shaking waterbath at $110 \mathrm{rpm}$ and $37^{\circ} \mathrm{C}$. After $30 \mathrm{~min}$ the bacteria were washed and resuspended in PBS to the same concentration. In experiments in which preabsorbed serum was used, equal volumes of serum and bacterial suspension, or for controls PBS, were mixed. The mixture was incubated with gentle shaking at $37^{\circ} \mathrm{C}$ or at $4^{\circ} \mathrm{C}$. After 30 min the serum was filter sterilised and used in the killing experiments at a final concentration of $10 \%$ (vol/vol). Antibody titres against the four $E$ coli and $B$ fragilis strains in normal and absorbed sera were measured with indirect immunofluorescence according to standard procedures, using FITC labelled rabbit antihuman immunoglobulins (Bio-Merieux, Charbonières les Bains, France). Complement depletion in these sera was measured by determining $50 \%$ haemolytic units $\left(\mathrm{CH}_{50}\right)$ as described by Mayer. ${ }^{13}$

\section{KILLING EXPERIMENT}

Reaction mixtures were prepared in sterile polypropylene tubes $(12 \times 75 \mathrm{~mm}$, Rofa Mavi, Beverwijk, The Netherlands), each containing $0.5 \mathrm{ml}$ of the polymorph suspension $\left(10^{7}\right.$ cells $\left./ \mathrm{ml}\right), 0 \cdot 1 \mathrm{ml}$ serum, $0.1 \mathrm{ml} E$ coli, $0.1 \mathrm{ml} B$ fragilis and $0.2 \mathrm{ml}$ gel-HBSS, unless otherwise stated. The reaction mixture was incubated in a Julabo Paramix shaking apparatus (Rofa Mavi) at $400 \mathrm{rpm}$ in a $\mathrm{CO}_{2}$ incubator with a humidified atmosphere of $95 \%$ air and $5 \% \mathrm{CO}_{2}$ at $37^{\circ} \mathrm{C}$. After $0,30,60$, and $90 \mathrm{~min}$ $0.1 \mathrm{ml}$ of the reaction mixture was suspended in 9.9 $\mathrm{ml}$ of distilled water to lyse the polymorphs. Viable counts of $E$ coli were carried out by plating serial dilutions on nutrient agar plates, which were incubated aerobically. Viable $B$ fragilis were counted by plating serial dilutions on BM agar supplemented with haemin and menadione and $50 \mu \mathrm{g} / \mathrm{ml}$ nalidixic acid, which inhibited the growth of $E$ coli. The plates were incubated for $48 \mathrm{~h}$ in the anaerobic chamber.

Statistical analysis was performed with Student's $t$ test.

\section{Results}

$E$ coli $\mathrm{EB} 1$ and $E$ coli $\mathrm{EB} 4$ were both killed by polymorphs when normal serum was present. $B$ fragilis BE1 was not killed, whereas about $70 \%$ of $B$ fragilis BE4 was killed after 90 min. None of these strains was affected by serum alone, and the anaerobes survived well the $90 \mathrm{~min}$ aerobic incubation in the killing experiments.

Both $B$ fragilis BE1 and BE4 significantly inhibited the killing of $E$ coli EB1 (Fig. 1; $p<0.01$ at 
30, 60, and $90 \mathrm{~min}$ ), but not of $E$ coli $\mathrm{EB} 4$ (Fig. 2). The inhibitory capacity of $B$ fragilis was found with whole cultures, with washed cells (as mentioned above), and with cells that had been killed by incubation for $1 \mathrm{~h}$ at $70^{\circ} \mathrm{C}$ (Table 1). A slightly smaller, but still significant, inhibition was found when washed cells which had been killed by formalin treatment were used. The supernatant of a BE1 culture and the BM medium itself had an inhibitory or rather a delaying effect on the killing of $E$ coli $\mathrm{EB} 1$ (Table 1); therefore, in further experiments washed cells of $B$ fragilis were used.

The inhibition of the killing was the result of the influence of $B$ fragilis on the serum. Incubation of the serum with the $E$ coli and $B$ fragilis strains resulted in loss of complement activity, as measured by $\mathrm{CH}_{30}$ determination (Table 2). $B$ fragilis BE1 had no inhibitory effect on the killing of preopsonised $E$ coli $\mathrm{EB} 1$. On the other hand, killing of EB1 in the presence of serum preincubated with $B$ fragilis $B E 1$ was significantly inhibited (Fig. $3 ; p<0.01$ at 30 , 60 , and $90 \mathrm{~min}$ ). In serum absorbed with EB1 itself, with $B$ fragilis BE4, and, for instance, with

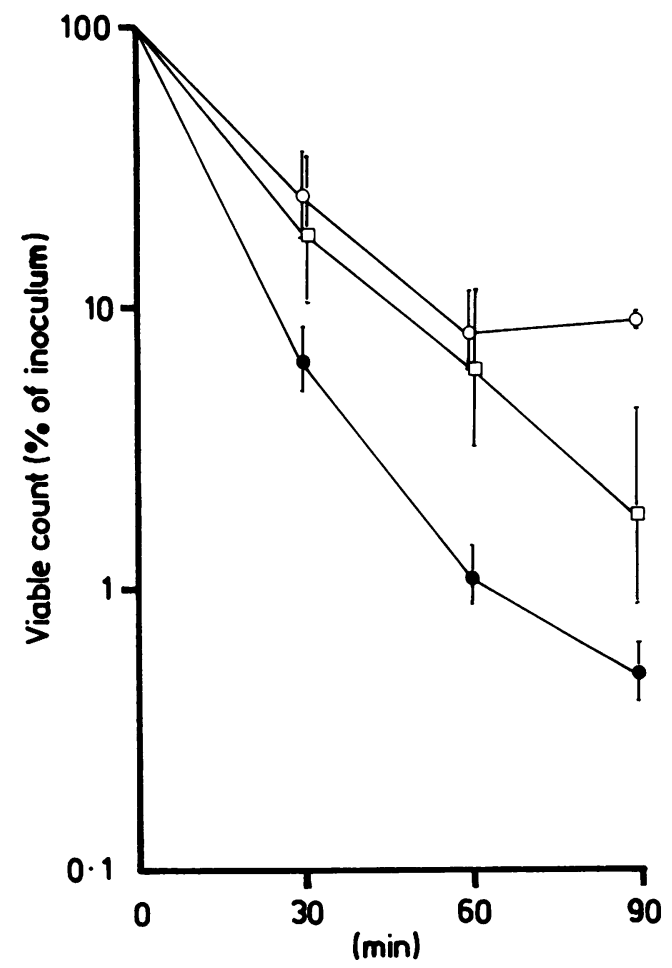

Fig. 1 Killing of $E$ coli $E B 1$ alone (-), in the presence of $B$ fragilis $B E 1$ (O_O) or $B$ fragilis $B E 4$ ( $\square-\square$ ). Each point represents the mean of at least four experiments and vertical bars indicate SEM.

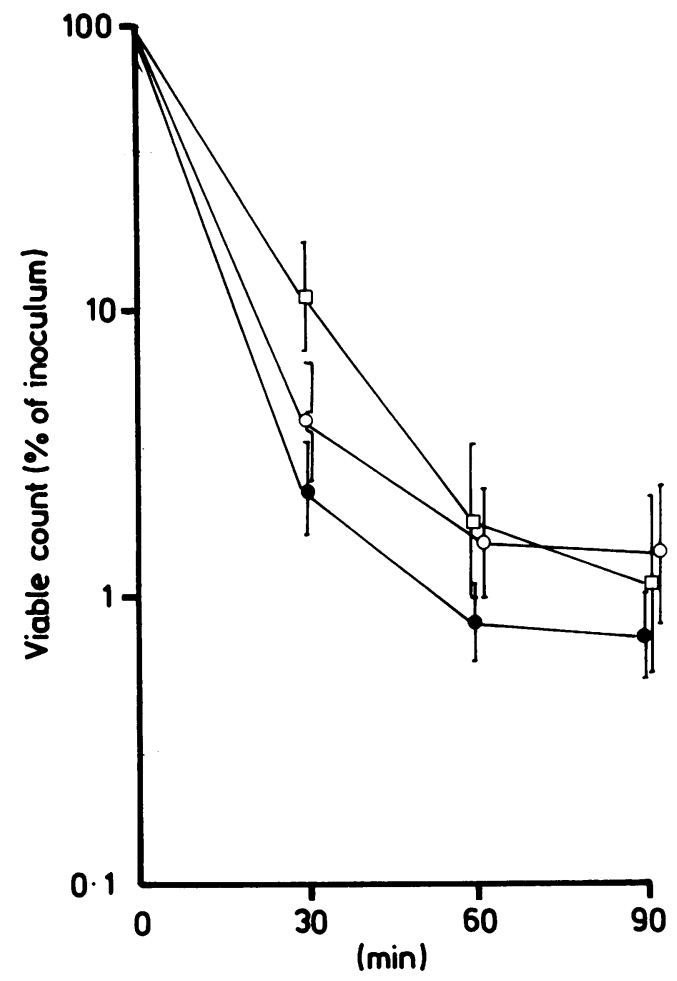

Fig. 2 Killing of E coli EB4 alone (presence of $B$ fragilis $B E 1(O-O)$ or $B$ fragilis $B E 4$ (口- $\square$ ). Each point represents the mean of at least four experiments and vertical bars indicate SEM.

Table 1 Killing by polymorphonuclear leucocytes of $E$ coli $E B 1$ in the presence of $B$ fragilis $B E 1$

\begin{tabular}{|c|c|c|c|}
\hline & \multicolumn{3}{|c|}{$\%$ of inoculum surviving after } \\
\hline & $30 \mathrm{~min}$ & $60 \mathrm{~min}$ & $90 \min$ \\
\hline \multirow{6}{*}{$\begin{array}{l}E \text { coli alone } \\
\text { with } B \text { fragilis } \\
\text { whole culture } \\
\text { with } B \text { fragilis } \\
\text { washed cells } \\
\text { with } B \text { fragilis heat } \\
\text { killed } \\
\text { with } B \text { fragilis } \\
\text { formalin killed } \\
\text { with } B \text { fragilis } \\
\text { supernatant } \\
\text { with BM medium }\end{array}$} & $16 \cdot 9(3 \cdot 0)$ & $3.8(0.9)$ & $1 \cdot 4(0 \cdot 1)$ \\
\hline & $81 \cdot 5\left(13 \cdot 8^{*}\right)$ & $38 \cdot 6\left(12 \cdot 7^{*}\right)$ & ND \\
\hline & $61 \cdot 2\left(6 \cdot 5^{*}\right)$ & $35 \cdot 7\left(7 \cdot 1^{*}\right)$ & $37 \cdot 2\left(9 \cdot 6^{*}\right)$ \\
\hline & $77 \cdot 7\left(8 \cdot 9^{*}\right)$ & $44 \cdot 0\left(12 \cdot 4^{*}\right)$ & $40.8\left(17 \cdot 2^{*}\right)$ \\
\hline & $67 \cdot 2\left(13 \cdot 4^{*}\right)$ & $16.4\left(8 \cdot 9^{*}\right)$ & $9 \cdot 9\left(3 \cdot 8^{*}\right)$ \\
\hline & $\begin{array}{l}90.3\left(7 \cdot 3^{*}\right) \\
83 \cdot 7\left(7 \cdot 7^{*}\right)\end{array}$ & $\begin{array}{l}11 \cdot 5\left(1 \cdot 8^{*}\right) \\
25 \cdot 7\left(14 \cdot 1^{*}\right)\end{array}$ & $\begin{array}{l}4 \cdot 1(1 \cdot 1 \dagger) \\
5 \cdot 1(1 \cdot 7 \neq)\end{array}$ \\
\hline
\end{tabular}

Values represent mean (standard error) of at least four experiments.

ND $=$ not determined.

Significance of difference from the killing of $E$ coli alone at the same incubation time: ${ }^{*} p<0.001, \dagger p<0.1, \neq p<0.01$.

Staphylococcus aureus killing of EB1 was com- $\mathbb{D}$ pletely inhibited (Table 3). In serum, absorbed with $E$ coli $\mathrm{EB} 4$, which, as shown in Table 2, uses com- 
Table 2 Depletion of complement in normal human serum by $E$ coli and $B$ fragilis

\begin{tabular}{llll}
\hline $\begin{array}{l}\text { Serum preincubated } \\
\text { with }\end{array}$ & \multicolumn{4}{l}{$\%$ of $\mathrm{CH}_{\mathrm{so}}$ after } \\
\cline { 2 - 4 } & $5 \mathrm{~min}$ & $15 \mathrm{~min}$ & $30 \mathrm{~min}$ \\
\hline PBS (control) & $89 \cdot 6(3 \cdot 6)$ & $84 \cdot 8(6 \cdot 3)$ & $84 \cdot 8(3 \cdot 0)$ \\
E coli EB1 & $77 \cdot 4(6 \cdot 1)^{*}$ & $69 \cdot 0(5 \cdot 0) \dagger$ & $44 \cdot 2(5 \cdot 8) \ddagger$ \\
E coli EB4 & $80.0(18 \cdot 0)^{*}$ & $65 \cdot 0(11 \cdot 0) \dagger$ & $55 \cdot 0(1 \cdot 0) 8$ \\
$B$ fragilis BE1 & $60.5(8 \cdot 1) \dagger$ & $40 \cdot 0(3 \cdot 4) \ddagger$ & $33 \cdot 0(3 \cdot 7) \ddagger$ \\
$B$ fragilis BE4 & $50.3(8 \cdot 7) \dagger$ & $6 \cdot 5(6 \cdot 2) \ddagger$ & $0 \cdot 3(0.3) \ddagger$ \\
\hline
\end{tabular}

Values represent mean (standard error) of at least three experiments.

Significance of difference from control: ${ }^{*}$ not significant, $t p<0.1$, $\ddagger \mathrm{p}<0.001,8 \mathrm{p}<0.01$.

Table 3 Killing of E coli EB1 in the presence of serum preincubated with $E$ coli, $B$ fragilis, and Staphylococcus aureus

\begin{tabular}{|c|c|c|c|}
\hline \multirow{2}{*}{$\begin{array}{l}\text { Serum pretreated } \\
\text { with }\end{array}$} & \multicolumn{3}{|c|}{$\%$ of inoculum surviving after } \\
\hline & $30 \min$ & $60 \mathrm{~min}$ & $90 \min$ \\
\hline $\begin{array}{l}\text { PBS (control) } \\
E \text { coli EB1 } \\
E \text { coli EB4 } \\
B \text { fragilis BE4 } \\
\text { Staph aureus }\end{array}$ & $\begin{array}{c}29.1(9.8) \\
121.0(4.6)^{*} \\
105.0(6.5)^{\dagger} \\
123.0(6.5)^{*} \\
131.0(13.0)^{*}\end{array}$ & $\begin{array}{c}2.8(1.6) \\
111.0(33.0)^{*} \\
88.2(31.0)^{\ddagger} \\
196.0(3.3)^{*} \\
145.0(1.9)^{*}\end{array}$ & $\begin{array}{c}1.5(0.8) \\
196(86.0) \dagger \\
56 \cdot 2(6 \cdot 8) \ddagger \\
430.0(118.0)^{*} \\
324.0(100.0)^{*}\end{array}$ \\
\hline
\end{tabular}

Values represent mean (standard error) of at least three experiments.

Significance of difference from control: ${ }^{*} \mathrm{p}<0.001$, $\mathrm{tp}<0.01$, $\ddagger \mathrm{p}<0.01$.

paratively little complement, killing was also inhibited, but not completely. When serum was treated with $B$ fragilis at $4^{\circ} \mathrm{C}$ instead of $37^{\circ} \mathrm{C}$, no inhibition of the killing of EB1 was found (Fig. 3). Therefore, competition for cross reacting antibodies could not have been responsible for the inhibition. This was confirmed when antibodies were determined with immunofluorescence: the antibody titre against each of the four strains was not affected by absorption with any of the other three, and only slightly reduced by absorption with the strain itself (data not shown). Complement was essential for the killing of $E$ coli EB1 but not of EB4, which was killed almost

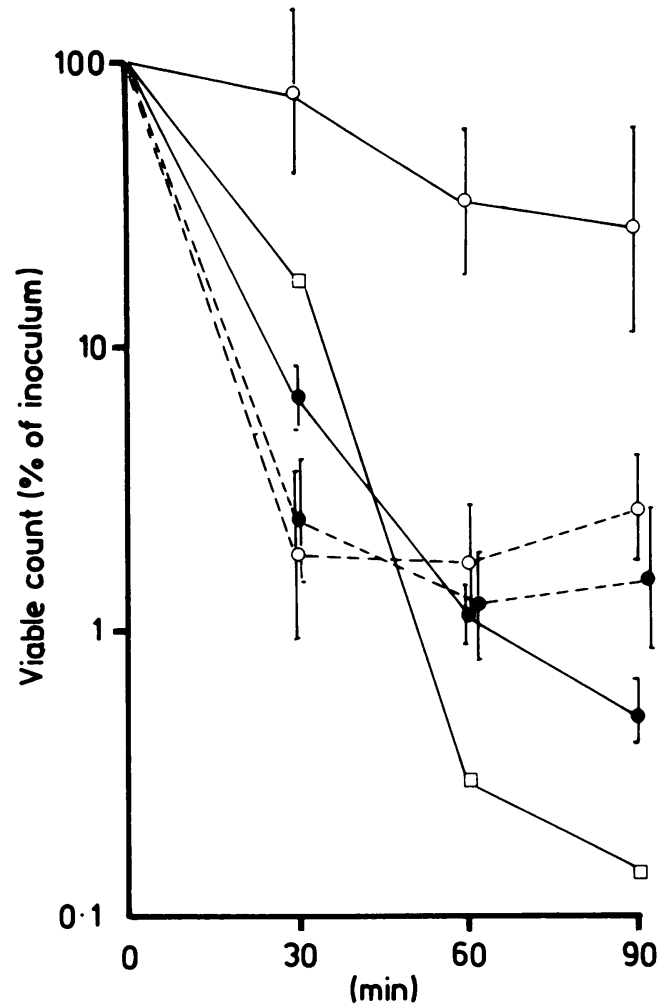

Fig. 3 Effect of $B$ fragilis BE1 on the killing of $E$ coli $E B 1$. Killing of $E$ coli alone (- $)$ and in the presence of serum pretreated with $B$ fragilis at $37^{\circ} \mathrm{C}$ ( $\mathrm{O} \bigcirc$ ) or at $4^{\circ} \mathrm{C}(\mathrm{\square} \longrightarrow \mathrm{C})$. Killing of preopsonised $E$ coli alone (O_- or in the presence of $B$ fragilis ( $-O$ ). Each point represents the mean of at least four experiments, except the points indicating the killing in the presence of serum treated with $B$ fragilis at $4^{\circ} \mathrm{C}$, which are the means of two experiments. Vertical bars indicate SEM.

as well in the absence of serum as in its presence (Table 4).

Thus of the two clinically isolated pairs of $E$ coli and $B$ fragilis only one pair showed synergy in the

Table 4 Killing by polymorphonuclear leucocytes of E coli EB1 and E coli EB4: effect of serum

\begin{tabular}{|c|c|c|c|}
\hline & \multicolumn{3}{|c|}{ \% of inoculum surviving after } \\
\hline & $30 \mathrm{~min}$ & $60 \min$ & $90 \min$ \\
\hline $\begin{array}{c}\text { E coli } \text { EB1 with normal serum } \\
\text { without serum } \\
\text { with inactivated serum* } \\
\text { E coli } \text { EB4 with normal serum } \\
\text { without serum } \\
\text { with inactivated serum* }\end{array}$ & $\begin{array}{c}16.9(3.0) \\
131.0(27 \cdot 5) \\
136.8(14.7) \\
6.1(1 \cdot 7) \\
25 \cdot 2(10 \cdot 1) \\
21.0(10.3)\end{array}$ & $\begin{array}{c}3.8(0.9) \\
150.6(39.7) \\
167.0(18.5) \\
2.0(0.8) \\
8.1(4.0) \\
3.2(1.9)\end{array}$ & $\begin{array}{r}1.4(0.4) \\
206 \cdot 4(74 \cdot 5) \\
331.3(32 \cdot 8) \\
1.5(0.6) \\
3.6(1.9) \\
1.2(0.4)\end{array}$ \\
\hline
\end{tabular}

Values represent mean \pm standard error of at least four experiments.

${ }^{*}$ Serum was inactivated by heating at $56^{\circ} \mathrm{C}$ during $30 \mathrm{~min}$. 
sense that the anaerobe inhibited the killing of the aerobe by polymorphs. The occurrence of this inhibition depended on the properties of the aerobenamely, on its requirement of complement for killing.

\section{Discussion}

In this study the inhibitory effect of two strains of $B$ fragilis on the killing of their aerobic partners was studied in vitro. Our results agree with the conclusions drawn when the pathogenic properties of these paired strains were tested in mice. ${ }^{9} B$ fragilis $B E 1$ and BE4 both have a substantial effect on the clearance of a low dose of subcutaneously injected $E$ coli EB1, and abscesses are the result. This phenomenon was not found with an equal dose of $E$ coli EB4, which shows that the synergy is dependent on the $E$ coli strain. Likewise, in vitro inhibition of killing is found for $E$ coli EB1, but not for EB4. This dependence of the inhibition of the killing on the $E$ coli strain used has also been described earlier by Wade et al. ${ }^{5}$ These authors do not state, however, whether $E$ coli 2882, the strain for which killing was not inhibited by $B$ fragilis in their experiments, was killed by polymorphs in the absence of serum, a phenomenon which explained the lack of inhibition of the killing of our strain $E$ coli EB4. The failure of Reznikov et $a^{10}$ to show any effect of $B$ fragilis on the clearance of $E$ coli in mice could also be due to the $E$ coli strain tested.

The results in this study are in agreement with the hypothesis that inhibition of the killing is the result of competition for opsonins and confirm the findings of other authors. ${ }^{1345}$ The dependence of the inhibitory power of $B$ fragilis on low redox potential, which was noted by some authors, ${ }^{13}$ was not confirmed. As in the report of Wade et al, ${ }^{5}$ suspensions of washed cells of $B$ fragilis in saline without addition of any reducing agent had the inhibitory effect. Perhaps this difference is related to the bacteria used as inhibitory organisms. The findings of Ingham et al ${ }^{1}$ and Jones and Gemmell $^{3}$ refer to $B$ melaninogenicus, a species which is much more sensitive to oxygen than $B$ fragilis. Namavar $e a^{4}$ found an inhibitory effect by culture filtrates but not by washed cells of $B$ gingivalis on the killing of Proteus mirabilis. It therefore seems likely that in the inhibition of the killing of aerobic bacteria by different species of bacteroides different mechanisms are concerned. According to Ingham et al ${ }^{1}$ merely increasing the numbers of the aerobe, or using other aerobes as inhibiting species, does not have the same effect. Our results confirm those of Wade et al, ${ }^{5}$ who found inhibition by Staph aureus of $E$ coli killing. It seems that any complement depleting organism can inhibit serum dependent killing of $E$ coli and that this in vitro phenomenon is achieved not only by anaerobes. Data are not given in the above mentioned reports, however, to indicate whether the inhibiting species themselves are killed by polymorphs. This might be important, since wasting of large amounts of complement on bacteria which are not killed subsequently would be more disadvantageous to the host than the use of complement for the destruction of a second infecting species.

It is not clear what part of the bacteroides cell is responsible for the inhibitory effect. The possession of a capsule is considered to be of great importance for virulence, ${ }^{14}{ }^{15}$ and encapsulation is reported to impair the phagocytosis of bacteroides cells, ${ }^{1617}$ The role of the capsule in the inhibition of the killing of other species is controversial, since experiments with purified capsular material give conflicting results. ${ }^{518}$ Moreover, the occurrence of capsules among different bacteroides species, within one species, and even within one strain is variable. ${ }^{19}$ From the report by Conolly et $a^{18}$ and from our own observations encapsulation does not seem to be related to inhibitory effects on the killing. Nevertheless, if the killing inhibiting effect is non-specific, as indicated by Wade $e t a^{5}$ and by this paper, the question remains unanswered why $B$ fragilis is encountered much more often in mixed abdominal infections than would be expected from its prevalence in the gut.

\section{References}

' Ingham HR, Sisson PR, Tharagonnet D, Selkon JB, Codd AA. Inhibition of phagocytosis in vitro by obligate anaerobes. Lancet 1977 ;ii:1252-4.

${ }^{2}$ Namavar F, van Vught AMJJ, MacLaren DM. Bacterial synergy in mixed aerobic/anaerobic infections. Lancet 1980; ;:659.

${ }^{3}$ Jones GR, Gemmell CG. Impairment by Bacteroides species of opsonisation and phagocytosis of enterobacteria. J Med Microbiol 1982;15:351-61.

4 Namavar F, Verweij AMMJJ, Bal M, van Steenbergen TJM, de Graaff J, MacLaren DM. Effect of anaerobic bacteria on the killing of Proteus mirabilis by human polymorphonuclear leukocytes. Infect Immun 1983;40:930-5.

$s$ Wade BH, Kasper DL, Mandell GL. Interactions of Bacteroides fragilis and phagocytes: studies with whole organisms, purified capsular polysaccharide and clindamycin-treated bacteria. $J$ Antimicrob Chemother 1983;17 (suppl C):51-62.

- Tofte RW, Peterson PK, Schmeling D, Bracke J, Kim Y, Quie PG. Opsonisation of four Bacteroides species: role of the classical complement pathway and immunoglobulin. Infect Immun 1980; 27: 784-92.

' Onderdonk AB, Bartlett JG, Louie T, Sullivan-Seigler N, Gorbach SL. Microbial synergy in experimental intra-abdominal abscess. Infect Immun 1976;13:22-6.

8 Kelly MJ. The quantitative and histological demonstration of pathogenic synergy between Escherichia coli and Bacteroides fragilis in guinea pig wound. J Med Microbiol 1978;11:51325. 
• Verweij-van Vught AMJJ, Namavar F, Sparrius M, Vel WAC, MacLaren DM. Pathogenic synergy between Escherichia coli and Bacteroides fragilis: studies in an experimental mouse model. J Med Microbiol (in press).

${ }^{10}$ Reznikov M, Finlay-Jones JJ, MacDonald PJ. Effect of Bacteroides fragilis on the peritoneal clearance of Escherichia coli in mice. Infect Immun 1981;32:398-9.

"Finegold SM. Anaerobic bacteria in human disease. New York: Academic Press, 1977:72-7.

12 Shah HN, Williams RAD, Bowden GH, Hardy JM. Comparison of the biochemical properties of Bacteroides melaninogenicus from human dental plaque and other sites. J Appl Bacteriol 1976;41:473-92.

${ }^{13}$ Mayer MM. Experimental immunochemistry. Springfield, Illinois: Charles C Thomas, 1964:149.

14 Onderdonk AB, Kasper DL, Cisneros RL, Bartlett JG. The capsular polysaccharide of Bacteroides fragilis as a virulence factor: comparison of the pathogenic potential of encapsulated and unencapsulated strains. $J$ Infect Dis 1977;136:82-9.

is Kasper DL, Onderdonk AB, Polk BF, Bartlett JG. Surface anti- gens as virulence factors in infection with Bacteroides fragilis. Rev Infect Dis 1979;1:278-90.

${ }^{16}$ Simon GL, Klempner MS, Kasper DL, Gorbach SL. Alterations in opsonophagocytic killing by neutrophils of Bacteroides fragilis associated with animal and laboratory passage: effect of capsular polysaccharide. J Infec Dis 1982;145:72-7.

17 Reid JH, Patrick S. Phagocytic and serum killing of capsulate and non-capsulate Bacteroides fragilis. J Med Microbiol 1984; 17:247-57.

${ }^{18}$ Conolly JC, McLean C, Tabaqchali S. The effect of capsular polysaccharide of Bacteroides fragilis on polymorph function and serum killing. J Med Microbiol 1984;17:259-71.

${ }^{19}$ Babb JL, Cummins CS. Encapsulation of Bacteroides species. Infect Immun 1978; 19:1088-71.

Requests for reprints to: Dr WAC Vel, Vrije Universiteit, School of Medicine, Department of Medical Microbiology and Parasitology, PO Box 7161, 1007 MC Amsterdam, The Netherlands. 